\title{
Die Nederduitse Gereformeerde Kerk en die Afrikanervolk kerkordelik verwoord
}

\author{
Strauss, Piet \\ Universiteit van die Vrystaat \\ straussp@ufs.ac.za
}

\begin{abstract}
The Dutch Reformed Church and the Afrikaner - in its church order

The Dutch Reformed Church (DRC) and the Afrikaner people had close ties in the 1960's. This was intensified by the apartheid system in South Africa. The policy of apartheid was supported by the DRC, most of the Afrikaners and the National Party in government.

In 1962 the DRC determined in its church order that it will protect and build the Christian-Protestant character of the Afrikaner people. This group was singled out by a church that was to be for believers of all nations. It also gave the DRC an active part in the development of this group.

The documents Church and Society-1986 and Church and Society-1990 changed all this. The close links between the DRC and Afrikaans cultural institutions ended and the DRC declared that it caters to any believer. The church order article about the Afrikaner was omitted.
\end{abstract}

Key words

Nederduitse Gereformeerde Kerk; Afrikanervolk; Volkskerk; Kerk en Samelewing; Kerkorde

\section{Probleemstelling: Nederduitse Gereformeerde Kerk 'n volkskerk?}

In 'n opstel met die sestigste verjaardag van Willie Jonker in 1989 verwys Jaap Durand na die situasie van die Nederduitse Gereformeerde Kerk (NGK) in die 1960's. 
"Die volkskerk! Die bastion van die Afrikaner! Soos selde in die SuidAfrikaanse kerkgeskiedenis het die dekade van die sestigers die implikasies van so 'n identifikasie van kerk en volksideale hulle so duidelik aangemeld, juis toe die Afrikaneraspirasies en politieke doelstellinge besig was om hulle toppunt te bereik" (Durand 1989:66).

Kortweg het die bedreiging van 'n volkskerk die NGK, aldus Durand, in hierdie tyd voor die dilemma geplaas dat "toewyding aan volksbelange vra wat in stryd is met die toewyding aan die belange van Gods koninkryk ..." (Durand 1989:67).

Die kerkorde van die eerste Algemene Sinode van die NGK in 1962 (NGKO1962: in bibliografie aangedui as NGKO-1964) bevat 'n artikel 67b wat sy hegte band met die Afrikanervolk verwoord.

"Die Kerk sal hom daarvoor beywer om die Protestants-Christelike karakter van ons volk te beskerm en uit te bou" (NGKO-1964:15).

In sy verwoording van 'n kerkordelike taak teenoor 'n bepaalde volk was NGKO-1962 uniek onder die gereformeerde kerkordes van sy tyd (Nauta 1971:466-473; Kruger et al 19661-10; Van Dellen en Monsma 1967:1-3). Boonop het die betrokke artikel die NGK nie net die opdrag gegee om die karakter van hierdie volk defensief te beskerm nie, maar aggressief uit te bou. Die begrip "ons volk" sonder om die volk by die naam te noem, was in die konteks natuurlik die Afrikanervolk. Die taak van die NGK om die karakter van "ons volk" te beskerm en uit bou het 'n band veronderstel wat vir die woordvoerders van destyds vanselfsprekend was. Anders gestel: almal in 1962 behoort te geweet het watter volk vir die Algemene Sinode van die NGK "ons volk" was. Almal in hierdie tyd moes ook kennis dra van die nou band tussen die NGK en die Afrikanervolk. 'n Band waarin die NGK breedweg ook'n volksbouer of karaktervormer van die volk was ${ }^{1}$.

Vrae wat hieruit ontstaan en wat in hierdie stuk ondersoek word, is die volgende.

1 In 2009 was die skrywer persoonlik betrokke by gesprekke tussen die ANC en die NGK. Eersgenoemde wou met die Afrikaner praat en het geoordeel dat hy daarvoor by die NGK moes begin. Hierdie verduideliking het gekom van die sekretaris-generaal van die ANC op die vraag hoekom die NGK by gesprekke met die Afrikaner betrek word? NGK 2011:207. 
Van waaruit het die hegte band tussen die NGK en die Afrikaner ontstaan? Hoe is die band sedert 1962 kerkordelik verwoord? Het 'n kerk in 'n bepaalde gebied 'n kerklike roeping teenoor "die" volk of volkere van sy omgewing? Is hierdie roeping 'n saak wat kerkordelik vasgelê moet word? Indien wel, waaruit bestaan die tipies kerkordelike taak van 'n gereformeerde kerk teenoor 'n volk of volkere? NGKO artikel 21 bepaal immers dat die kerk sake "vanuit kerklike perspektief, in die lig van die Woord van God en op kerklike wyse" hanteer (NGKO-2013:7). Hoe moes of moet hierdie kerklike wyse in die kerkordelike optrede van die NGK teenoor die Afrikanervolk gestalte kry?

\section{Hegte volksband in die 1960's}

Die hegte band van die NGK met die Afrikanervolk soos verwoord in NGKO-1962 kom in 'n tyd waarin Afrikanernasionalisme 'n hoogbloei beleef. In 1961 word 'n belangrike historiese Afrikanerideaal in die SuidAfrikaanse samelewing verwesenlik. Die land word 'n Republiek. Daarmee volg 'n stap wat in sy kern draai om die herstel van die Boererepublieke van die Vrystaat en Transvaal wat teen die einde van die Anglo-Boereoorlog in 1902 beëindig is. Die bestaan van hierdie twee republieke was die kulminasiepunt van talle Boererepublieke wat deur Afrikaners in SuiderAfrika in die agtiende en negentiende eeue gestig is (Grobler 2007: 4043,74-108; Pretorius 2012:152). Onafhanklike Boererepublieke wat 'n uitdrukking was van die staatkundige aspirasies van Afrikaners. Veral sedert die Groot Trek van 1835-1840, deur republiekwording in 1961 én daarna het daar groot staatkundige gebeure op inisiatief van Afrikaners plaasgevind op die sogenaamde "Pad van Suid-Afrika" - 'n term wat destyds gebruik is (Grobler 2007:162). Deur die Nasionale Party was Afrikaners staatkundig die pasaangeërs in die land met morele en praktiese steun uit ander instansies van hulle "volkslewe". Hierby is - reg of verkeerd Afrikaanse kerke waaronder die NGK en Afrikaanse kultuur-, onderwysen ander organisasies ook betrek. As nie-staatlike instellings was hulle ondersteuners van 'n byna lewensomvattende wetlike apartheid in SuidAfrika.

Vir baie Afrikaners was die oorname van die Nasionale Partybewind in 1948 en die koms van 'n republiek in 1961 simbole van 'n Afrikanertriomf. Vanuit die noue band tussen kerk, staat en volk is daar in kerk en volk 
verwys na "ons regering". Op sy beurt is daar in die NGK - én in die Nasionale Regering - gepraat van "ons volk".

NGKO-1962 met sy artikel 67b was hiervan die amptelike kerklike kroon: die NGK beywer hom vir die beskerming en uitbouing van die ProtestantsChristelike karakter van "ons volk".

Histories en prinsipieel was daar meer as een rede vir hierdie nou band.

Die voorloper van dié band kom in 1652 saam met die Hollander Jan van Riebeeck na die Kaap. Van Riebeeck en sy 90 bemanningslede kom vanuit'n gereformeerd georiënteerde Nederland wat hulle samelewing as 'n eenheid of 'n teokratiese verbondsgemeenskap beskou. In hierdie beskouing was kerk en staat twee kante van dieselfde muntstuk. Hulle wat die lidmate van die staatsbevooregte Gereformeerde Kerk was, was ook die burgers van die staat, die "Koninkrijk der Nederlanden". Dieselfde volk het kerk en staat gevorm, sodat hierdie kerk goedskiks ook van "ons regering" en "ons volk" sou kon praat. Wat meer is, die Nederlandse kerk, staat en volk het vanuit dieselfde vertrekpunte oor die samelewing gedink en in mekaar bondgenote gevind (Pont 1988:38-53).

Die breë lyne van hierdie beskouing sou in die sestigerjare van die twintigste eeu onder Afrikaners, in die NGK as 'n Nederlandsgereformeerde kerk ${ }^{2}$ van geboorte en die Republiek van Suid-Afrika as die staatkundige kant daarvan, naleef. Vanuit 'n gemeenskaplike Christelike lewensbeskouing is apartheid Bybels begrond, God in die grondwet van 1961 erken, Christelike onderwys in 1967 in wetgewing vervat én sabbatswetgewing - alles voorbeelde - gehandhaaf. Onder die vaandel van 'n Christelike land en 'n Christelike volk het Afrikaners "hulle eie vaderland" bewoon. Blanke Engelssprekendes sou nog as medeburgers aanvaar kon word, maar gekleurdes moes elders geakkommodeer word. Die minderheid Engelse uit die Eerste Wêreld was 'n kleiner waagstuk vir 'n eenheidstaat gebou op demokratiese waardes as die meerderheid swart mense en gekleurdes uit oorspronklik - die Derde Wêreld.

2 Vgl Strauss, PJ 2015: 4-5, 8-9. Die Nederduitse dui op Nederland as die "lage landen" of laer Duitsland en die gereformeerd op die belydenisskrifte, kerkorde en regering van die NGK wat na die Nasionale Sinode van Dordrecht van 1618-1619 in Nederland teruggevoer kan word. 
Te midde van wêreldwye kritiek en druk op die Suid-Afrikaanse regering na die skietery by Sharpeville in Maart 1960 en die onrus en protes uit die swart gemeenskap wat daarop gevolg het, kom die band tussen die NGK en "ons regering" besonder skerp na vore in NGKO-1962 artikel 65. Hierin verklaar die Algemene Sinode van 1962 dat hy hom onderwerp aan die "gesag en wette van die staat" indien dit nie "met Gods Woord bots nie". Die "Kerk aanvaar met dankbaarheid (LW-PS) die beskerming deur die owerheid" en sy "vryheid van godsdiens in belydenis en byeenkoms, met dien verstande dat genoemde vryhede nie misbruik sal word om die fondamente van die staatsgesag te ondergrawe of om wanorde op publiekregtelike terrein te veroorsaak nie" (NGKO-1964:14). Die NGK is skerp bewus van sy band met sy geloofs- en volksgenote op die regeringsbanke. Meer pastoraalinnig en kerklik-solidêr kan 'n sinode hom nouliks uitspreek!

Teen hierdie agtergrond is NGKO-1962 artikel 67b nie net uniek vir 'n gereformeerde kerkorde nie. Die weglating van die naam van "ons volk" laat niemand wat die NGK en sy destydse omstandighede ken, in die duister oor van wie hier gepraat word nie. In kerk en staat is "ons" Afrikaners gesamentlik onder druk vanweë "ons" beleid wat in dié tyd - onder HF Verwoerd - afsonderlike ontwikkeling gerig op eventuele gelykheid, genoem is. Hierdie eventuele gelykheid is deur die jare bestempel as 'n maatstaf vir geregtigheid (Strauss 1983:56).

\section{Betrokkenheid by kultuurorganisasies}

Onder die destydse vlagskip van die NGKas'n beskermer en uitbouer van die Protestants-Christelike karakter van die Afrikanervolk, is dit nie ongewoon dat NGK-instansies tot ongeveer 1982 by Afrikaanse kultuurliggame affilieer of inskakel nie. Van die bekendste kultuurorganisasies waarby geaffilieer word, is die Federasie van Afrikaanse Kultuurorganisasies (FAK).

As gevolg van besware teen affiliasie omdat die kerk dan onder die gesag van kultuurliggame staan én opereer op nie-kerklike terreine met niekerklike maatstawwe, word affiliasie mettertyd verander na "meewerkende" liggame. Hierdie woordspeling bevredig egter nie op die lang duur nie. Die kerk was steeds kultureel besig onder die gesag van kultuurorganisasies. 
Juis met die oog op die FAK neem die Algemene Sinode van 1982 'n negatiewe besluit oor die affiliasie van kerklike instellings by kultuurorganisasies (NGK 1982:1432). In hierdie tyd adviseer die Algemene Regskommissie van die Algemene Sinode sy Breë Moderatuur dat kerklike liggame 'n eiesoortige (geloofs)roeping en struktuur het sodat affiliasie "met enige vereniging", hoe lofwaardig sy doelstellings ook al is, "onmoontlik" is. Met betrekking tot die Federale Vroueraad Volksbelang - die oogmerk blyk uit die naam - adviseer die Regskommissie egter dat indiwiduele vrouelidmate "met bepaalde gawes en talente" lede word van organisasies wat op 'n "positief Christelike grondslag" staan en so die koninkryk van God bevorder. Die NGK moet hom nie amptelik kompromitteer nie, maar verleen kragtens NGKO-1978 artikel 67 (NGKO-1978:18) sy "medewerking aan maatskaplike organisasies wat op 'n positief Christelike basis georganiseer is". Vroueaksies as deel van die NGK kan egter nie "as sodanig” by die Vroueraad Volksbelang betrokke raak nie (NGK 1986:54).

Hierdie bepaling in NGKO-1962 en sy opvolgers (vgl dieselfde bewoording by NGKO-2013:19 artikel 69) onder die opskrif "kerk, maatskappy en vrye vereniging" is ook uniek in gereformeerde kerkordes en spruit aanvanklik ook uit die positiewe volksklimaat in die NGK van die 1960's (Strauss 2014:134). Dié gemaklike affiliasie van NGK-instellings by kultuurorganisasies verdwyn egter in die 1980's. In hierdie tyd herbesin die NGK oor sy verhouding met die Afrikanervolk in die dokumente Kerk en Samelewing-1986 en Kerk en Samelewing 1990 (KS-1986 en KS-1990). In teenstelling met NGKO-1986 wat dit nog gewysig bevat, verskyn NGKO1990 sonder die nou bekende volksartikel uit 1962 (NGKO-1986:20; NGKO-1990:19).

Die neerslag van 'n positiewe volksklimaat in die NGK rondom NGKO-1962 dra waarskynlik daartoe by dat indiwidue in amptelike kerklike posisies hulle terselfdertyd in besture van kultuurorganisasies en vrye verenigings onderskei. Reeds voor 1962 tree bekende NGK-predikante soos DF Malan en NJ van der Merwe uit die bediening toe tot die Suid-Afrikaanse politiek. 'n Toetrede wat vanuit die hegte band tussen kerk, volk en staat spruit. Malan word die Eerste Minister in 1948 en Van der Merwe is die Vrystaatse leier van die Nasionale Party, Hoofleier van Die Voortrekkers én voorsitter van die FAK tot sy dood in 1940. Albei glo vanuit 'n lewensomvattende Christelike wêreldbeskouing dat hulle God steeds dien, hoewel op 'n ander 
terrein met 'n ander roeping (Strauss 1998:57; Grobler 2007:161; Gaum et al 2008:1122).

$\mathrm{Na} 1962$ word hierdie tendens deur indiwiduele NGK-predikante voortgesit. Hoewel vele dominees in Afrikaanse kultuurorganisasies werk, word enkele bekendes hier uitgesonder.

Met sy minsame geaardheid en droë, gevatte humorsin word ds Dawie Beukes in 1974 die voorsitter van die Algemene Sinode van die NGK. In hierdie tyd is hy ook ses jaar lank die voorsitter van die FAK (Gaum et al 2008:111). Professor Carel Boshoff wat van 1967 tot 1988 sendingwetenskap aan die Universiteit van Pretoria vir NGK-studente doseer, is 'n skoonseun van dr HF Verwoerd (in wie se spore hy die Afrikanergebied Orania inisieer), die voorsitter van die Suid-Afrikaanse Buro vir Rasse-aangeleenthede en die Afrikaner Broederbond én Hoofleier van Die Voortrekkers - alles in die laaste twee dekades van die twintigste eeu (Gaum et al 2008:128). Professor JA Heyns is die voorsitter van die Algemene Sinode van 1986, die Sinode van KS-1986 waartoe hy 'n groot bydrae lewer (Strauss 2011:512). Hy sorg vir ten minste 40 paragrawe in hierdie dokument (Williams 2006:196-198; 405-406). Hy word in die 1980's ook voorsitter van die Suid-Afrikaanse Akademie vir Wetenskap en Kuns. In 1993 word hy voorsitter van die FAK en ondervoorsitter van die Afrikanerbond (Williams 2006:347, 353). Volgens Theron was een van die groot temas in Heyns se lewe om met kerk en kultuur "in die reine te kom" (Theron 1988:157). Vir Heyns self lê sy hoogste lojaliteit by God en sy Woord. 'n Lojaliteit wat nie deur hierdie "volkse" verbintenisse in gevaar gestel word nie. In die jongste tyd is professor Piet Strauss die voorsitter van die Algemene Sinode van 2007 en Hoofleier van Die Voortrekkers (2001-2013).

\section{Kerk en volk in die koninkryk, vir die NGK en sy ampsdraers}

'n Sentrale tema in hierdie betrokkenheid van die NGK en indiwiduele predikante by die Afrikaner en sy kultuurorganisasies is dat kerk en volk nie teenoor of vreemd aan mekaar hoef te staan nie. Vanuit 'n koninkryksperspektief is al twee in diens van God en moet hulle mekaar vanuit hierdie gesamentlike vertrekpunt 'n eie ruimte en 'n eie diens aan God gun. Wat meer is, in die koninkryk vind kerk en volk 'n 
gemeenskaplike waardestelsel van waaruit hulle mekaar kan versterk en elk vanuit sy terrein of aard kan aanvul en verryk (Gaum et al 2008:456; NGK 1986:51-52). Die NGK moet profeties krities én waarderend met die volk en sy georganiseerde kultuur omgaan, terwyl laasgenoemde die kerk kan versterk om sy gebruik van taal en kultuur in die uitdra van die Evangelie op datum te bring.

Onder die volksartikel van die NGKO kon die NGK kerklik-profeties op die Protestants-Christelike begrip van Afrikaners konsentreer. Met dié woorde gee die artikel ten minste die regte invalshoek van 'n moontlike kerklike betrokkenheid by "die volk". Die probleem van die artikel as 'n saak wat vanuit 'n kerklike perspektief op 'n kerklike wyse hanteer moet word, lê nie hier nie. Dit lê by die "beskerm" en "uitbou": by die NGK as 'n interne vormer van die karakter van "ons volk". Die alleenverwysing na die Afrikanervolk in sy kerkorde is ook 'n fout. Behalwe dat die kerk van Christus op alle volke gerig moet wees, was daar in die laaste helfte van die twintigste eeu reeds Portugese, Engelse en Nederlandse gemeentes in die algemene sinodale verband van die NGK self. Daarby was die NGK in gesprekke oor die eenheid van die veeltalige en veelvolkige NG Kerkfamilie gewikkel (Strauss 2010:135-142).

Of NGKO-1962 (NGKO-1964:15) tot NGKO-1986 (NGKO-1986:20) waaronder NGKO-1966 (NGKO-1966:19), NGKO-1970 (NGKO-1970:19), NGKO-1974 (NGKO-1974:17), NGKO-1978 (NGKO-1978:19) en NGKO1982 sy gewraakte artikel oor die NGK en "ons volk" bevat het of nie, vanuit 'n gemeenskaplike lewensbeskouing of -vertrekpunt sou die NGK, indiwiduele predikante en ander lidmate in elke geval by die georganiseerde Afrikanerkultuur betrokke raak. Hierdie indiwidue vorm 'n lewende bewys dat 'n Christelike lewensperspektief en koninkryksdiens nie tot die kerklike bediening beperk hoef te wees nie. Of, soos betoog deur Flip Theron, hierdie betrokkenheid spruit waarskynlik by sommige uit die motief dat die genade die natuur nie moet ophef nie, maar moet deursuur en kersten (Theron 1988:168).

Die protesgeskrif Geloof en Protes (GP-1987) van beswaardes in 1987 op $K S$-1986, 'n beweging waaruit die Afrikaanse Protestantse Kerk in 1988 kom, beweer dat 'n volk sy eie kerk moet hê. 'n Ware kerk is 'n eksklusiewe volkskerk (Voortsettingskomitee 1987:11). In sy antwoord namens die Algemene Sinodale Kommissie van die NGK wys Heyns daarop - hy is op 
daardie stadium die voorsitter van die kommissie - dat die kerk nie aan die volk behoort nie, maar aan God. In die kerk gaan dit nie primêr om "ons kultuur" nie, maar om die "koninkryk van God". Die lewensbloed van die kerk is nie die kultuur nie, maar die vergote bloed van Christus op Golgota. Die oorsprong van die kerk is nie die natuur nie, maar die genade (Heyns 1988:10, 11). Heyns eggo of verwoord dus Theron se opmerking.

Was die NGK 'n volkskerk? Het die Algemene Sinode deur sy kerkorde die belange van die Afrikaner in die laaste helfte van die twintigste eeu bo die belange van Gods Koninkryk gestel? Is Durand se vrees in dié verband kerkordelik bewaarheid?

Op die reg en verkeerd van NGKO artikel 67b wat tot 1986 gehandhaaf is, is by implikasie reeds gewys. Die kern van artikel $67 \mathrm{~b}$ naamlik dat die Afrikaner sy "volkslewe" Protestants-Christelik moet lei, is egter nie weerspreek nie. Daarteen is daar in die debat geen blyke van kritiek nie.

Die vraag is nou: het die nuwe ontwikkelinge soos uitgedruk in KS-1986 en KS-1990 hieraan verander? Het die gewysigde bewoording van NGKO na 1986 'n nuwe deuntjie gesing? Waarop dui die weglating uit NGKO van “ons volk" na 1986? Is hierdie sake deurentyd op 'n kerklike wyse hanteer?

Daar reeds daarop gewys dat artikel 67b waarskynlik min of geen rol in die betrokkenheid van NGK-lidmate by “ons volk" gespeel het nie. Die artikel het in elke geval geen kerkordelike kanaal (Strauss 2010:4) of bepaling bevat waardeur die NGK die Protestants-Christelike karakter van die "volk" kon beskerm en uitbou nie. In kerkordetaal was NGKO artikel 67b meer 'n houding as 'n kerkordelike bepaling. Die artikel het niks aan die kerklike praktyk verander nie. Dit was nie noodsaaklik nie en kon maar daar gelaat word.

Was NGKO artikel $67 \mathrm{~b}$ 'n bepaling wat toegee aan Afrikanervolksbelang ten koste van 'n kerklike en koninkryksbelang?

\section{5. 'n Nuwe benadering in die tagtigs}

KS-1986 en KS-1990 sou die Afrikaner nie uit die NGK verban nie. 'n Nuwe benadering in 'n veranderde situasie was egter in hierdie dokumente sigbaar. Die "innige verbondenheid" van die NGK met die Afrikanervolk was steeds daar (KS 1986:51; KS 1990:38). 


\subsection{KS-1986}

KS-1986 loop op die tema "Die Ned Geref Kerk en die Afrikanervolk” egter langer as sy onmiddellike opvolger KS-1990. By 'n nadere ontleding van die dokumente wil dit voorkom asof KS-1986 met sekere omskrywings nog elemente van 'n minder Bybelse en 'n meer volkse of volksbepalende bedeling bevat wat voor 1986 in sommige kringe aanvaar is. KS-1990 skakel sekere probleme uit en formuleer die saak suiwerder. Omskrywings in KS1986 wat nie weer in KS-1990 voorkom nie, illustreer hierdie punt.

Volgens KS-1986 is die volk 'n "ruimte waarbinne die kerk sy roeping vervul" sonder om sy identiteit as kerk in te boet. Kerk en volk moet egter nie met mekaar vereenselwig word nie. Die NGK is nie 'n volkskerk waarin jou volkswees jou kerkwees bepaal nie.

Die probleem hier met KS-1986 lê egter in die woordjies "ruimte waarbinne". 'n Ongespesifiseerde inbeweeg van 'n kerk - die NGK - in die kulturele ruimte van 'n volk - die Afrikanervolk - of in die gedaante van die betrokke volk, skep die moontlikheid dat die kerk ook in die norme vergestalt in die kulturele gebruike van so 'n volk kan opgaan. Die onderskeid tussen Bybelse konstantes wat onder alle omstandighede vir alle mense en volke geld en die uitlewing daarvan in 'n bepaalde kultuurof volkstyl of op 'n bepaalde styl, kan hierdie formulering verbeter. Die kerk binne die "ruimte" van 'n volk is onnodig beperkend en veralgemenend. Met die Woord van God as sy instrument staan die kerk soms "in" en soms "buite" of teenoor die volk. Dit gaan hier eerder om 'n kerklike bediening aan die volk met 'n lewensomvattende invloed op en in die volk én op en in ander samelewingskringe.

Hierteenoor voer GP-1987 aan dat die NGK 'n belydeniskerk "binne volksverband" is. Volk en kultuur bepaal die vorm, gestalte en lewe van die kerk ... Volgens GP-1987 is 'n eksklusiewe volkskerk soos die ChristenAfrikaanse kerk 'n “ware” kerk (Voortsettingskomitee 1987:11). 'n Term

3 'n Voorbeeld van so 'n volkskerkbenadering is waarskynlik die NGK in die OranjeVrystaat wat in 1937 deur sy Sinode besluit om teywer virvolksmonumente by Bloedrivier, Vegkop en Winburg. 'n Ywer wat nie tevergeefs was nie. Die Voortrekkermonument by Winburg is byvoorbeeld in 1968 ingewy en moontlik gemaak met die hulp van die destydse (Afrikaansoorheersde) Vrystaatse Provinsiale Administrasie. Hierdie monument moes die Vrystaatse "antwoord" wees op die Voortrekkermonument in Pretoria. 
wat wel in die Nederlandse Geloofsbelydenis gebruik word, maar daarin van 'n ander inhoud voorsien word.

Die "volk" as 'n omvattende samelewingskring loer oor die horison as KS-1986 aanvoer dat 'n besef of gevoel van die "eie" deur "allerlei samelewingsverbande" versterk word. Hierdie versterking geskied in die kerk, huwelik, gesin, groter families, die volk as 'n kulturele en die nasie as 'n politieke grootheid. Kortom, die eie word gevoed en deur "allerlei" maatskaplike, kulturele, ekonomiese, akademiese, professionele, politieke en ander organisasies én die kerk en gemeente. Binne hierdie kringe oefen die "gemeenskapsbesef 'n sterk invloed uit". Myns insiens kan "die" gemeenskapsbesef hier egter beperkend op die verkondigingswerk van die kerk wees. As "die gemeenskapsbesef" en "die volk" hier as sinonieme gebruik word, neig "die volk" tot 'n bepalende omvattende samelewingskring waaraan ander kringe ongenuanseerd maar beslissend blootgestel is. Op hierdie punt gebruik KS-1986 ook die woordjie "getemper" as dit praat oor die liefde vir die eie groep in verhouding met ander groepe. Die bedoeling is duidelik, maar dit sou beter wees om te sê dat liefde vir die eie én ander groepe alles eenvoudig "aan die eise van God se Woord" moet voldoen om nie in spanning met mekaar te verkeer nie. Dit gaan nie oor te veel of te min of 'n getemperde liefde vir die eie nie, maar oor dit wat reg is (KS-1986:51). Dit gaan om 'n gemeenskapsbesef of, liewer, 'n gemeenskaplike kulturele styl, wat op elke terrein van die lewe 'n uitkoms is van die beginsels of konstantes wat daardie lewenskring bepaal. Dit gaan om 'n gemeenskaplike styl waaraan die lede van die volk deel het, maar wat op elke terrein die draers is én moet wees van die konstantes van daardie terrein.

KS-1986 sluit sy paragrawe oor die NGK en die Afrikanervolk af met 'n goedbedoelde, maar verkeerde voorbeeld van rassisme. Volgens die dokument kan die "eie" oorbeklemtoon word ten koste van ander groepe se lewensruimte en -moontlikhede. Hierdie beklemtoning is 'n sondige verabsolutering en vertoon kenmerke van rassisme. Tereg veroordeel die NGK so iets "onvoorwaardelik" (KS-1986:52). Gemeet aan KS se eie onderskeidings van ras as 'n "biologiese" en volk as "kulturele" begrip (KS1986: 19-22) kan 'n verabsolutering van die eie volk letterlik geneem egter nie rassisme wees nie. Rassisme beteken nie diskriminasie op grond van kultuurverskille nie, maar op grond van rasbiotiese verskille. $K S$-1986 skep 
hiermee die indruk dat hy rassisme in elke geval wou bykom, ongeag die vraag of dit draai rondom volks- of rasseverskille.

Aan die positiewe kant erken KS-1986 die "goeie reg" van liefde vir die eie volk. KS-1986 praat van 'n gemeenskapsbesef wat in die verskillende samelewingskringe 'n sterk invloed uitoefen. 'n Invloed wat lei tot liefde, trots en waardering vir die eie geskiedenis, eie kultuurwaardes en -gebruike, taal en simbole. Hierdie liefde vir die eie volk moet egter ingebed word in die Bybelse liefdesgebod van doen aan jou naaste soos aan jouself (KS-1986:22). Bygesê: die sentrale liefdesgebod van die Bybel met sy liefde tot God en die naaste gee balans en perspektief aan die veelfasettige menselewe.

\section{$5.2 \mathrm{KS}-1990$}

In teenstelling met $K S$-1986 verwys $K S$-1990 nie na hierdie omstrede punte nie. Boonop sny KS-1990 die saak heelwat korter.

KS-1990 erken ook die "goeie reg" van liefde vir die eie volk en "kultuurwaardes". Hierdie liefde moet egter gelouter of gesuiwer word deur die liefde vir Christus en sy koninkryk wat alle ander liefdes in die menslike bestaan te bowe gaan en in perspektief plaas. Liefde vir die eie mag nooit waardering vir ander se "waardes en kultuur" uitskakel nie. Volksverafgoding lei tot diskriminasie teenoor ander en moet in SuidAfrika met sy verskeidenheid tot "verontregting" lei. Soos KS-1986 eindig $K S$-1990 hier met 'n verwysing na die gebod van doen aan jou naaste soos aan jouself (KS-1990:38).

KS-1986 en KS-1990 verskil maar kom ook ooreen met NGKO-1962 oor die NGK en Afrikaner.

Die verskil lê in die feit dat die lewe van die Afrikaner - anders as in NGKO-1962 - nie geïsoleerd beskryf word nie, maar konsekwent as saam met ander volke. Enige verwysing in KS na die Afrikaner vind binne Suid-Afrika en breër met 'n bewustelike mense- en volkereverskeidenheid plaas. In die denke van $K S$ sou 'n enkele kerkorde-artikel gerig op slegs die Afrikaner met die uitsluiting van of sonder enige verwysing na ander, ondenkbaar wees. Apartheid Suid-Afrika met die "Pad van Suid-Afrika" as die pad van die Afrikaner was teen 1986 vir die NGK net nie meer 'n realiteit nie. Nie in reële terme nie, maar ook nie in beginsel nie. KS-1986 
praat dus - ondermeer - van 'n "plurale" en KS-1990 van 'n "multikulturele" samelewing (KS-1986:61; KS-1990:44; Strauss 1992:952).

Teen hierdie agtergrond sou die Algemene Sinode van 1990 NGKO artikel $67 \mathrm{~b}$ nie langer handhaaf nie. Die konsekwensies van die houding van die Algemene Sinode van 1986 en 1990 oor die NGK en die Afrikaner sou eers by die Algemene Sinode van 1990 deurwerk om in die NGKO neerslag te vind. 'n Beskrywingspunt van die Sinode van Midde-Afrika wat mik op 'n weglating van die volksartikel in NGKO verwys ook na 'n nuwe houding oor die NGK en die Afrikaner in KS (NGK 1990:437).

Die ooreenkoms van KS-1986 en KS-1990 met NGKO-1962 artikel 67b oor die NGK en die Afrikanervolk lê in die Protestants-Christelike (NGKO) of koninkryksrigting (KS) wat die Afrikaner in sy volkswees moet inslaan. NGKO praat egter van 'n Protestants-Christelike karakter van "ons volk" wat so byna 'n blywende en onaantasbare beeld daaraan verleen, terwyl KS hou by die "te bowe" gaan, "louter" en "suiwer" van die kultuur deur algemeen geldige of normatiewe koninkrykseise. Eise wat op alle mense van toepassing is en impliseer dat geredde sondaars hieraan gehoorsaam moet wees om God in alles hier op aarde te dien. Dit is ook nie onmoontlik dat NGKO met sy Protestants-Christelike karakter van "ons volk" - dus ongekwalifiseerd verwoord - neig na 'n volksidealisme nie. 'n Volkskarakter wat as 'n soort volksgees of -siel die optrede van hierdie volk bepaal. Met sy koninkrykseise vaar KS hier in suiwerder Skriftuurlike waters. Die verbondswet of tien gebooie van die Here soos uitgelê deur die Heidelbergse Kategismus kan goedskiks netso as koninkrykseise vir God se lewensomvattende ryk in die geskape wêreld geneem word. Die sentrale liefdesgebod as 'n opsomming van hierdie gebooie is op die totale lewe gerig. Deuteronomium 6 vers 4 vat dit saam: Luister Israel, die Here is ons God, Hy is die enigste Here. Daarom moet jy die Here jou God liefhê met hart en siel, met al jou krag (NAV 1983:196).

\section{Die volksartikel weggelaat}

Die aanvaarding van KS-1986 het inderdaad vir die NGK rondom kerk en volk, en dan spesifiek ook die Afrikanervolk, 'n nuwe bedeling ingelui. Dit word ook sigbaar uit gemelde beskrywingspunt van die Sinode van Midde-Afrika aan die Algemene Sinode van 1990 oor die volksartikel in 
NGKO 1986 (NGK 1990:437), die beskrywingspunt van die Dagbestuur van die Sinodale Kommissie van Wes-Transvaal oor dieselfde saak (NGK 1990:441) én die voorstel in die verslag van die Algemene Jeugkommissie oor, nou, NGKO artikel 69. Hierdie voorstel wou NGKO artikel 69.1 oor die NGK en die onderwys wysig en in die proses sommer ook by die volksartikel in 69.2 uitkom (NGK 1990:184). Op die ou end is die voorstel van die Jeugkommissie aanvaar waarmee die twee beskrywingspunte eintlik vanselfsprekend verval het (NGK 1990: 712). Tog gee al drie hierdie voorstelle in hulle motivering blyke van die nuwe situasie waarin die NGK hom bevind.

Midde-Afrika voer aan dat die volksartikel in NGKO is stryd is met KS1986. Volgens hierdie Sinode moet "kerk" en "volk" duidelik van mekaar onderskei word en die NGK as 'n belydeniskerk teenoor 'n volks- of staatskerk gehandhaaf word. Die kerk is nie vyandig teenoor die volk nie, maar ook nie in diens van die volk nie. By implikasie is die NGK dus ook nie in diens van die Protestants-Christelike karakter van "ons volk" of die Afrikanervolk nie. Die kerk is die kerk van Christus en nie van die volk nie. Om alle misverstand hieroor uit die weg te ruim, moet die volksartikel in NGKO geskrap word. Daarby wys Midde-Afrika daarop dat die NGK reeds onder verskillende taal- en volksgroepe in verskillende lande arbei. Die indruk wat die volksartikel by hierdie mense kan laat is dat hulle 'n tweederangse plek in die NGK inneem wat primêr tog maar'n kerk van die Afrikanervolk is. Volgens Midde-Afrika het die volksartikel wat onder die tema "Kerk en Onderwys" voorkom, eintlik nie met laasgenoemde te make nie (NGK 1990:437). Op sy beurt stel die Dagbestuur van die Sinodale Kommissie van Wes-Transvaal voor dat artikel 69.2 verdwyn omdat die lidmate van die gemeentes van die NGK uit meer as een volk kom (NGK 1990:441).

Albei die motiverings van hierdie beskrywingspunte gebruik - in die lig van die tydsgewrig en verstaan van die kerk - ter sake argumente. Op die moontlikheid dat die NGK volgens die volksartikel in diens van die Afrikanervolk kon wees, is reeds gewys. Vir die NGK met sy gemeentes en lidmate uit meer as een taal- en kultuurgroep om van "ons" volk te praat, gaan nie op nie. Midde-Afrika kom reeds in 1986 met 'n beskrywingspunt wat vra vir die skrapping van NGKO artikel 69.2. Ongelukkig gee hulle geen motivering nie. Die Tydelike Regskommissie probeer die saak besweer of 'n 
moontlike krisis red deur voor te stel dat "ons" volk met "die" volk vervang word (NGK 1986:558). Hiervoor gee die kommissie egter geen motivering nie. Sy voorstel word wel die besluit van die vergadering (NGK 1986:701). Teen 1986 het die woorde van die artikel dus verander, maar die betekenis dieselfde gebly (NGKO-1986:20). "Die" volk kon tog niks anders as "ons" volk wees nie. Tensy dit'n mislukte poging was om daarvan die volk in die algemeen of alle volke te mak. Die vervanging van "ons" met "die" het egter nie die beskrywingspunte van 1990 ontmoedig of van argument laat verander nie.

In sy voorstel het die Algemene Jeugkommissie met sy bewoording oor die onderwys die volk by wyse van woorde weggelaat, maar by implikasie tog hanteer. Die opskrif van artikel 69 naamlik "Kerk en Onderwys" is gehandhaaf. Artikel 69.2 het die verwysing na 'n Protestants-Christelike karakter behou, maar hierdie byvoeglike naa mwoord is verbind aan kultuurgedifferensieerde onderwys. Die voorstel is deur die Algemene Sinode aanvaar. Daarmee het hy - so is besluit - ook die twee beskrywingspunte hanteer (NGK 1990: 712).

Tussen die notule of handelinge van die Sinode en die uitgawe van die gedrukte NGKO, het 'n ander woord met 'n ander betekenis egter ongekontroleerd ingesluip. Kultuur-gedifferensieerd het verander na kultuur-georiënteerd (NGKO-1990:19). Daarmee is die vraag geskep of die onderwys Protestants-Christelik georiënteerd of bepaald is of kultuurgeoriënteerd of bepaald? Protestants-Christelik dui tog op die basisrigting of oriëntering van die onderwys wat kulturele gestalte aanneem. Laasgenoemde is belangrik, maar het te make met die gestalte en styl van die onderwys eerder as die rigting. Anders gesê: onderwys sonder 'n kulturele gestalte het geen adres en geen gesig nie ...

Hoe dit ook al sy, die volksartikel met sy voetangels vir 'n gereformeerde kerk, is uit NGKO geskryf.

Hierdie houding is bevestig met die hersiening van NGKO in 1998. Die NGK sou hom nou daarvoor beywer dat die Woord van God en Protestants-Christelike norme en waardes "rigtinggewend" in alle onderwysaangeleenthede is: ook vir die kultuuridioom waarin dit plaasvind (NGKO-1998:26). Die volk het verdwyn, maar die onderwys in die algemeen - die keer van alle gemeenskappe - moes Protestants- 
Christelik gestuur word: dit moes ook die kultuuridioom waarin die onderwys in elke geval plaasvind, stuur. So kan die Protestants-Christelike karakter van "ons volk" dalk ook positief beïnvloed word. Die een volk van NGKO was weg en meer volke of kulture in die onderwys is gevisualiseer, maar so sou die kultuur van hierdie volk - die Afrikaner - naas ander tog sy aandag kry.

\section{Slot}

Die eerste NGKO - uit 1962 - was ten opsigte van die NGK en die Afrikanervolk 'n kind van sy tyd. Dit blyk uit twee lastige verskynsels. Eerstens is die Afrikaner in NGKO-1962 alleen uitgesonder as die volk oor wie se karakter die NGK as 'n kerk van Christus vir almal, besorg is. Tweedens was die NGK van voorneme om hierdie karakter aktief te beskerm en uit te bou. 'n Voorneme wat die NGK 'n aktiewe "volkspeler"(!) sou mak. Hierdie hegte band met die Afrikanervolk het die situasie van die NGK in die 1960's weerspieël.

Die volksartikel in NGKO het egter eers in NGKO-1990 verval. Een van die redes hiervoor is waarskynlik dat die artikel nie 'n groot rol in die NGK gespeel het nie en daarom vir 'n lang tyd nie onder die aandag was nie. Hierdie skynbare ongeërgdheid blyk ook uit drukfoute in hierdie artikel wat soms tussen die handelinge van sinodes en die gedrukte kerkorde voorkom.

In KS-1986 en KS-1990 het die NGK'n ander rigting as in NGKO ingeslaan. Daar is uitdruklik gesê: die NGK is oop vir alle mense van alle kulture (KS-1986:46). Dit het nie beteken dat die NGK koud teenoor enige volk of kultuur staan nie. In sy profetiese taak en vanuit koninkryksperspektief moes die NGK hom steeds met "die" volk, maar so ook met alle volke wat sy pad kruis, bemoei. In $K S$ wou die NGK sy moontlike etiket van 'n volkskerk afskud.

Intussen verreken die NGK volkskultuur steeds in sy metodes van bediening. 


\section{Bibliografie}

Durand, JJF 1989. Willie Jonker en die Nederduitse Gereformeerde Kerk. In: Theron, PF en Kinghorn, J. Koninkryk, kerk en kosmos. Bloemfontein: Pro Christo, 64-73.

Gaum, F et al. 2008. Christelike Kernensiklopedie. Wellington: Lux Verbi BM.

Grobler, J 2007. Uitdaging en antwoord. 'n Vars perspektief op die evolusie van die Afrikaners. Brooklyn: Grourie.

Heyns, JA 1988. Antwoord van die Ned Geref Kerk op Geloof en Protes. Sl:sn.

Kerk en Samelewing (KS) 1986. 'n Getuienis van die Ned Geref Kerk.

Bloemfontein: Pro Christo.

Kerk en Samelewing (KS) 1990. 'n Getuienis van die Ned Geref Kerk.

Bloemfontein: Pro Christo.

Kruger, LS et al (Du Plessis, HLM; Spoelstra, B; Spoelstra, TT) 1966.

Handleiding by die Kerkorde van die Gereformeerde Kerk in SuidAfrika. Potchefstroom: Pro Rege.

Nauta, D 1971. Verklaring van de Kerkorde van de Gereformeerde Kerken in Nederland. Kampen: Kok.

Nederduitse Gereformeerde Kerk (NGK) 1966. Handelinge van die Algemene Sinode. Sl:sn.

Nederduitse Gereformeerde Kerk (NGK) 1982. Handelinge van die Algemene Sinode. Sl:sn.

Nederduitse Gereformeerde Kerk (NGK) 1986. Handelinge van die Algemene Sinode. Sl:sn.

Nederduitse Gereformeerde Kerk (NGK) 1990. Handelinge van die Algemene Sinode. Sl:sn

Nederduitse Gereformeerde Kerk (NGK) 2011. Handelinge van die Algemene Sinode. Sl:sn. 
Nederduitse Gereformeerde Kerk (NGKO) 1964. Kerkorde. Kaapstad: NG Kerk-Uitgewers.

Nederduitse Gereformeerde Kerk (NGKO) 1966. Kerkorde (gebruik as NGKO-1962). Pretoria: NG Kerkboekhandel.

Nederduitse Gereformeerde Kerk (NGKO) 1970. Kerkorde. Pretoria: NG Kerkboekhandel.

Nederduitse Gereformeerde Kerk (NGKO) 1974. Kerkorde. Pretoria: NG Kerkboekhandel.

Nederduitse Gereformeerde Kerk (NGKO) 1978. Die Kerkorde. Pretoria:

NG Kerkboekhandel van Transvaal.

Nederduitse Gereformeerde Kerk (NGKO) 1982. Die Kerkorde. Pretoria:

NG Kerkboekhandel van Transvaal.

Nederduitse Gereformeerde Kerk (NGKO) 1986. Die Kerkorde. Pretoria:

NG Kerkboekhandel van Transvaal.

Nederduitse Gereformeerde Kerk (NGKO) 1990. Die Kerkorde. Pretoria: NGKB.

Nederduitse Gereformeerde Kerk (NGKO) 1994. Die Kerkorde. Wellington: Hugenote-Uitgewers.

Nederduitse Gereformeerde Kerk (NGKO) 1998. Die Kerkorde. Wellington: Hugenote-Uitgewers.

Nederduitse Gereformeerde Kerk (NGKO) 2013. Die Kerkorde. Sl:sn.

Nuwe Afrikaanse Vertaling (NAV) 1983. Die Bybel. Kaapstad: Bybelgenootskap van SA.

Pont, AD 1988. Die Gelofte van 1838 - 'n Poging om die teologiese agtergrond daarvan te peil. In: Pont, AD (red). Die Gelofte van 1838. Pretoria: Kital.

Pretorius, F (red) 2012. Geskiedenis van Suid-Afrika. Van voortye tot vandag. Kaapstad: Tafelberg. 
Strauss, PJ 1983. Die Nederduitse Gereformeerde Kerk en die Gereformeerde Kerke in Nederland: Betrekkinge rondom die SuidAfrikaanse Rassevraagstuk. Pretoria: UP (Ongepubliseerde DDproefskrif).

Strauss, PJ 1992. Kerk, staat en politieke modelle in "Kerk en Samelewing-1990". HTS 48/3 en 4: 943-956.

Strauss, PJ 1998. NJ van der Merwe: tipiese Afrikaanse neo-Calvinis van die twintiger- en dertigerjare? NGTT 41/1 en 2, 54-64.

Strauss, PJ 2010. Kerk en orde vandag. Bloemfontein: Sunmedia.

Strauss, PJ 2011. Kerk en samelewing in die dokumente "Kerk en samelewing" na 25 jaar. NGTT 52/3 en 4, 511-520.

Strauss, PJ 2014. Kerk, maatskappy en vrye verenigings. 'n Studie van die Kerkorde van die Ned Geref Kerk. Acta Theologica 34/2, 134-146.

Strauss, PJ 2016. Die naam "Nederduitse Gereformeerde Kerk". Acta Theologica 36/1, 213-228.

Theron, PF 1988. Natuur en genade, kerk en volk. In: Wethmar, CJ en Vos, CJA (red). 'n Woord op sy tyd. Pretoria; NG Kerkboekhandel, 157-172.

Van Dellen, I en Monsma, M 1967. The revised church order commentary. Grand Rapids: Zondervan.

Voortsettingskomitee 1987. Geloof en protes. Sl:sn.

Williams, HH 2006. Johan Heyns en die NG Kerk en apartheid. Bloemfontein: Ongepubliseer (D Th-proefskrif). 